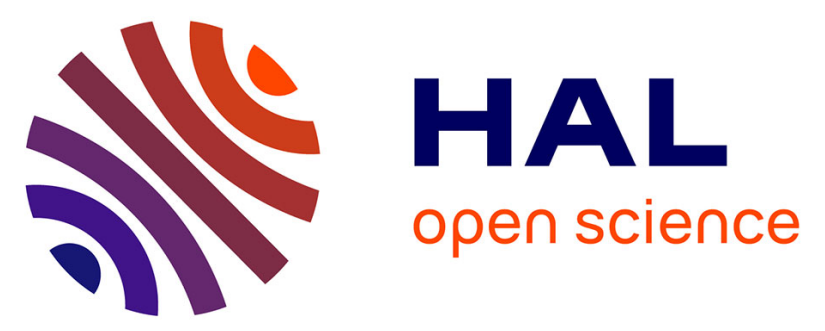

\title{
Effect of NBR-waste on rheological properties of modified bitumen and the mechanical characteristics of the asphalt mix.
}

Khedoudja Soudani, Véronique Cerezo, Smaïl Haddadi

\section{To cite this version:}

Khedoudja Soudani, Véronique Cerezo, Smail Haddadi. Effect of NBR-waste on rheological properties of modified bitumen and the mechanical characteristics of the asphalt mix.. Numerical Analysis of Nonlinear Coupled Problems. GeoMEast 2017, Springer, pp.203-213, 2017, Sustainable Civil Infrastructures, 978-3-319-61904-0. 10.1007/978-3-319-61905-7_18. hal-01627903

\section{HAL Id: hal-01627903 \\ https://hal.science/hal-01627903}

Submitted on 2 Nov 2017

HAL is a multi-disciplinary open access archive for the deposit and dissemination of scientific research documents, whether they are published or not. The documents may come from teaching and research institutions in France or abroad, or from public or private research centers.
L'archive ouverte pluridisciplinaire HAL, est destinée au dépôt et à la diffusion de documents scientifiques de niveau recherche, publiés ou non, émanant des établissements d'enseignement et de recherche français ou étrangers, des laboratoires publics ou privés. 


\title{
Effect of NBR-waste on rheological properties of modified bitumen and mechanical characteristics of the asphalt mix.
}

\author{
Khedoudja. Soudani ${ }^{1}$, Véronique. Cerezo ${ }^{2}$, Smail. Haddadi ${ }^{1}$ \\ ${ }^{1}$ USTHB, Laboratory of Environment, Water, Works and Geomechanics (LEEGO), Algiers, Algeria, \\ soudani.khedoudja@yahoo.com. \\ ${ }^{2}$ IFSTTAR, Environmental Assessment, Safety and Eco-design Laboratory, Nantes, France.
}

\begin{abstract}
Under the effect of severe climatic conditions and heavy vehicles traffic, premature and irreversible damages occur on road pavements carried out with conventional bituminous materials.

To deal with this situation, one of the most efficient way is the modification of bitumen by adding polymers. Moreover, use of waste polymers to modify bitumen is a promising solution in view of protecting environment.

The properties of modified bitumen are determined through rheological tests. This led to a better knowledge of bitumen behavior under various thermal and mechanical conditions.

In the present work, properties of modified bitumen by NBR-waste (waste of sole of shoes) are assessed and compared to the properties of 40/50 penetration grade bitumen. Then, mechanical characteristics of asphalt mixes are determined by using Marshall test. Rheological tests are performed with a Haake Rheostress 1 rheometer. Frequency and temperature sweep tests in oscillatory shear are performed within the linear viscoelastic range of the materials. Results show that NBR-waste influences bitumen rheology, by increasing viscoelastic function and decreasing phase angle. The NBR-waste bitumen is characterized by higher stiffness and elasticity, due to an increase of the elastic (storage) modulus G'. Also, the NBR-waste improves rheological behavior of bitumen. We have also achieved a marked increase in the Marshall quotient, which reflects an improvement of the mechanical performances of waste NBR modified asphalt.
\end{abstract}

\section{INTRODUCTION}

The increasing demand for transportation generates higher and heavier level of traffic. When combined with severe weather conditions, it leads to the rapid deterioration of pavement. The main approach used for preventing this deterioration is an improvement of the materials properties used for roads construction (Köfteci, 2014). In Algeria, flexible pavements are the most commonly used in road construction. The sustainability and the performances of these pavements are strongly related to the characteristics of their components (bitumen and aggregates).

However, under severe conditions, limits of use for conventional bitumen have been reached (AIPCR, 1999). The modification of bitumen with polymer is considered as one solution to overcome this problem (Gonzalez, 2004); (Airey, 2002). Nevertheless, the cost of modified bitumen represents an increase from 60 to $150 \%$ by comparison with pure bitumen prices. Thus, the use of recycled materials can be a significant economical 
alternative (Aguiar-Moya, 2013).

During the last years, a huge volume of waste estimated at 13.5 millions of tons per year were produced in Algeria. However, recycling activity remains limited to 5-6\% of this volume and mainly concerns paper and plastic materials. The rest is landfilled which raises a lot of issues regarding land use and urban development. Thus, the use of nonbiodegradable polymer waste in road construction can effectively contribute to the development of a sustainable national strategy according to Djemaci (2011). On one hand, it would allow diminishing the area dedicated to landfilling and on the other hand it could improve the performances of mixes using local raw materials. Several research projects were recently launched to address this issue.

The purpose of the present work is to study effect of waste industrial polymer (NBR) on bitumen and asphalt mix performances. Three modified blends are tested and the effect on their rheological behavior and on their mechanical properties are investigated, especially at high temperature considering the extreme weather conditions in Algeria.

\section{EXPERIMENTS}

\section{Raw materials}

Bitumen

A 40/50 penetration grade bitumen (pure bitumen) is used. It is supplied by NAFTAL company. The main physical properties of the bituminous material are given in Table 1

Modifying agent (waste industrial polymer)

The modifying agent is supplied by S.A.E.L. (Company of Application of elastomers). It is the acrylonitrile butadiene rubber (NBR) obtained from the milling shoe soles. The polymer NBR is an industrial waste blackish color, used as a crumb, composed of particles smaller than $0.8 \mathrm{~mm}$. The density of the crumb is 1.25 .

\section{Aggregates}

Crushed aggregates are used in this work. They are obtained from el Hachimia quarries located in the north of Algeria. Table 2 summarizes the main characteristics of the aggregates. The chemical analysis shows that these aggregates are calcareous.

\section{Preparation of polymer-bitumen blends}

The strategy for manufacturing blends must take into account environmental impacts based on energy consumption) in order to propose an efficient building process. According to previous researches (Haddadi, 2007) (Haddadi, 2008) (Soudani, 2010), the blends are prepared by using a mechanical stirring in a vertical low shear mixer with a speed of $600 \mathrm{rpm}$ for 2 hours at $180 \pm 5^{\circ} \mathrm{C}$.

Different contents of waste NBR are considered (2, 3 and $4 \%$ of bitumen weight). The modified blends are denoted by $\mathrm{BW}_{\mathrm{i}}$, were i refers to the waste NBR content.

\section{Preparation of asphalt mixes}

The control mix is prepared using Marshall Design Method ASTM D1559. Fig. 1 shows the specification limits for aggregates and the selected gradation for the control mix. The standard dimensions of the samples are $63.5 \mathrm{~mm}$ height and $101.5 \mathrm{~mm}$ diameter, produced with 50-blow compaction per side with Marshall Compactor. The final 
combined aggregate gradation is given in Fig. 1. The optimum asphalt content was found at 5.8 percent. The modified asphalt mixes are then obtained by mixing aggregates and waste-NBR modified bitumen. The samples are denoted by Mi where i refers to the waste NBR content used to modify bitumen.

\section{Testing program}

Conventional bitumen tests

Pure and modified bitumens are assessed through standardized penetration test (NF EN 1426) and softening point test (EN 1427).

\section{Dynamic shear rheometer test}

The dynamic shear rheometer (DSR) test is carried out in accordance with the procedures described in the AASHTO TP5 standard test method. The rheological properties are measured with a Haake Rheostress 1 using a plate-and-plate geometry (20 mm diameter). Frequency and temperature sweep tests in oscillatory shear measurements are performed. Frequency sweep runs are applied over a range from 0.01 to $10 \mathrm{~Hz}$ under isothermal conditions $\left(60^{\circ} \mathrm{C}\right)$. Temperature sweep runs are applied over a range from 50 to $90^{\circ} \mathrm{C}$ at $10 \mathrm{rd} / \mathrm{s}$ according to AASHTO T315-10 (AASHTO, 2010). The DSR is used to measure rheological properties (complex shear modulus $\mathrm{G}^{*}$ and phase angle $\delta$ ) of neat bitumen and waste (recycled) NBR-modified bitumen. These values are used to determine $\mathrm{G}^{*} / \sin \delta$ value, which is defined as a criterion for high temperature (good viscoelastic) performance of bitumen once in pavement according to SHRP (Strategic Highway Research Program) tests (Gonzalez, 2004) (Zhang, 2009). Moreover, higher $\mathrm{G}^{*} / \mathrm{sin} \delta$ values are well correlated with higher rutting resistance. Thus, $\mathrm{G}^{*} / \mathrm{sin} \delta$ must be superior to $1 \mathrm{kPa}$ for un-aged bitumen to minimize rutting risk (Golzin, 2011).

\section{Marshall test}

Mechanical characteristics of the hot Asphalt Mixtures are determined through Marshall test according to ASTM D1559.

Marshall stability value matches to the maximum load stand by the bituminous material at a loading rate of $50 \mathrm{~mm} /$ minute.

The flow value refers to the vertical deformation when the maximum load is reached. Marshall stability is related to the resistance of bituminous materials to distortion, displacement, rutting and shearing stresses. (Vincent, 2010) and the flow value reflects the plasticity and flexibility properties of asphalt mixtures. Flow has a linear inverse relationship with internal friction (Uzun, 2012). The ratio of stability to flow is important and not their individual values. It may be used to give an indication of mixture stiffness, and also as a measure of the material's resistance to permanent deformation in service (Malkoc, 2012).

\section{RESULTS AND DISCUSSION}

\section{Conventional bitumen tests}

Standardized tests are first conducted in order to identify the effect of waste NBR on physical properties of the bituminous binders. The results are summarized in Table 3. 
They show a slight increase of softening point values and penetration values when increasing waste NBR content, which can be connected to an increase of the viscoelasticity of the modified bitumen.

\section{Dynamic shear rheometer test results}

Some rheological parameters - viscoelastic function $\left(\mathrm{G}^{\prime}\right.$ and $\mathrm{G}^{\prime \prime}$ the elastic and storage modulus) and $\delta$ (phase angle) - are determined for both pure and modified bitumens. To analyze the rheological behavior of these different blends, isochronal and isothermal representations are used.

\section{Rheological Properties at High Temperature}

Fig. 2 shows isochronal curve at $10 \mathrm{rd} / \mathrm{s}$ of the viscoelastic function for pure and waste NBR modified bitumens at temperatures ranging from 50 to $90^{\circ} \mathrm{C}$. In all cases, values of $\mathrm{G}^{\prime}$ and $\mathrm{G}^{\prime \prime}$ tend to decrease as temperature increases. Also, one can observe that elastic modulus of modified bitumen increases with increasing NBR waste content. Regarding the loss modulus, values are slightly different from those obtained with unmodified bitumen. Moreover, they stay similar for different quantities of NBR.

The phase angle $\delta$ values obtained with the different blends are provided in Fig. 3. This parameter is a measure of the viscoelastic behavior of the material (Isacsson, 1999). Experimental results clearly show a decrease of $\delta$ values when increasing waste NBR content. The highest elastic response (increased $\mathrm{G}^{\prime}$ and decreased $\delta$ ) is obtained for the blend containing $4 \%$ waste NBR. As NBR waste is an elastomer, its incorporation into bitumen increases the elasticity of the binder at high temperatures. This is recommended to improve resistance to permanent deformation (Navarro, 2007).

Plots of $\mathrm{G}^{*} / \sin \delta$ versus temperature are displayed in Fig. 4. According to a SHRP test, the temperature at which $\mathrm{G}^{*} / \sin \delta=1 \mathrm{kPa}$ indicates the maximum temperature for good viscoelastic performances of the binder used in road pavement.

Road pavements in the north of Algeria can undergo very high temperatures (approximately to $60^{\circ} \mathrm{C}$ ) (Ramond, 2000) (Merbouh, 2010), which can cause permanent deformations or "rutting".

However, waste NBR polymer addition does not lead to any relevant bitumen modification according to this "rutting parameter". This is might be due to the small increase in the loss modulus $G$ " for these blends which slows the increase of the shear modulus $\mathrm{G} *$ values.

Nevertheless, it is important to underline that SHRP rutting criterion was suggested as an indicator of the resistance of the bituminous material to rutting (Bahia, 1995) but the rutting phenomenon is influenced by several other factors (Nguyen, 2006).

Fig. 5 shows the influence of waste NBR on the linear viscoelastic functions with frequency at $60^{\circ} \mathrm{C}$ for the different blends. At this temperature, incorporation of waste NBR in bitumen increases both storage modulus $\mathrm{G}^{\prime}$ and loss modulus $\mathrm{G}^{\prime \prime}$ over the entire range of frequency studied. This increase is higher for the $\mathrm{G}^{\prime}$ than for $\mathrm{G}^{\prime \prime}$. This improvement is more visible at low frequency. Moreover, it can be observed that polymer content does not influence the evolution of $\mathrm{G}^{\prime \prime}$ values. 
Fig. 6 shows the evolution of $\tan \delta$ which represents the inverse of the stored (elastic) energy with frequency. It can be seen that waste NBR tends to reduce $\tan \delta$ which clearly shows the effect of increasing the elasticity of the binder at high temperatures.

\section{Marshall test}

Test was conducted both on mixtures containing waste NBR and mixture prepared with the neat bitumen (control specimens). Each result is obtained from an average of three test specimens (Fig. 7). The Marshall flow values are all within the Algerian specification limits (2004). However, waste NBR contributes to decrease flow values but the values do not significantly change when increasing the quantity of NBR. The Marshall quotient values (Fig. 8) indicate higher values for the modified mixtures than for reference mixture. The Marshall quotient tends to increase with the quantity of waste NBR. We can notice that asphalt mix with $4 \%$ of waste NBR provides optimal result (i.e. high stiffness and it's likely more resistant to permanent deformation).

\section{CONCLUSIONS}

The aim of this study is to assess the impact of waste polymeric compound (NBR) extracted from shoe soles on the rheological properties and mechanical characteristics of road asphalt pavement mixes.

According to manufacturing conditions of modified bituminous binders, rheological properties at high temperature are improved, but the level of improvement is still moderate when compared with the published researches about crumb rubber modified bitumen. This may be due to the low content of modifying agent $(<5 \%)$ or the low quantity of light fractions of our bitumen (40/50) which are necessary for polymer dispersion.

The mechanical characteristics of modified asphalt mixes show visible improvement, particularly in Marshall quotient. Asphalt mix with 2\% of NBR gives the best level of performances.Moreover, relationship can be observed between asphalt mix mechanical characteristics and their rheological properties at high temperature. This indicate that high viscoelastic properties can contribute to improve the stiffness of the asphalt mix and its behavior towards permanent deformations. This conclusion must be confirmed by other experiments such as rutting test. The result would be promising for the recycling operation, due to satisfying results obtained with high content of waste NBR.

\section{REFERENCES}

Köfteci S, et al (2014). Performance evaluation of bitumen modified by various types of waste plastics. Constr Build Mater. 30 déc 2014;73:592-602.

AIPCR 1999. Emplois des bitumes spéciaux, des liants bitumineux modifiés et avec additifs en techniques routières. Laboratoire Central des ponts et chaussées.

Gonzalez O, et al (2004). Rheology and stability of bitumen/EVA blends. Eur Polymer J 2004; 40: 2365-72.

Airey GD (2002) . Rheological evaluation of ethylene vinyl acetate polymer modified bitumens. Constr Buil Mater; 16 (18): 473-487.

Aguiar-Moya JP et al (2013). Use of Waste Products as Bitumen Modifiers in Costa Rica. EATA, 
«Algérie-focus,» 28 août 2013. [on line]. Available: http://www.algeriefocus.com/blog/2013/08/le-non-recyclage-coute-300-millions-deuros-par-an-alalgerie/.

Djemaci B, al. La Géstion Intégrée des Déchets Solides en Algérie. Contraintes et Limites de sa Mise en Oeuvre. [on line]. Available: http://www.ciriec.ulg.ac.be/fr/telechargements/WORKING_PAPERS/WP1104.pdf.

Haddadi S, Ghorbel E, Laradi N. Effects of the manufacturing process on the performances of the bituminous binders modified with EVA. Constr Buil Mater 2008; 22: 1212-19.

Haddadi S 2007. Influence de la poudrette de caoutchouc sur le comportement au fluage des enrobés bitumineux.PHD thesis FGC/USTHB.

Soudani.K et al. Influence Process of Modification of Bituminous Concrete by the NBR On The Mechanical And Rheological Characteristics. In 2010.

American Association of State Highway and Transportation Officials. Standard Methode of test for determining the rheological properties of asphalt binder using dynamic shear rheometer(DSR). AASHTO designation T315-10, 2010

Zhang J,al 2009. Evaluation of the improuved properties of SBR/ weathered coal modified bitumen containing carbon black. Constr Buil Mater; 23: 2678- 87.

Golzin Y, al (2011). Improving the performance of Crumb Rubber bitumen by means of Poly Phosphoric Acid (PPA) and Vestenamer additives. Constr Buil Mater; 25: 3108-16.

Vincent T. H. CH. A Self-Learning Manual Mastering Different Fields of Civil Engineering Works (VC-Q\&A Method) U, July 2010.

Uzun İ, et al 2012. Evaluation of andesite waste as mineral filler in asphaltic concrete mixture. Constr Build Mater.;31:284-8.

Malkoc G, al (2012). Improving mechanical properties of hot-mixed asphalt using plastic waste (polyethylene terephthalate). In: 5th Eurasphalt \& Eurobitume Congress, Istanbul.

Isacsson, al 1999. Characterization of bitumens modified with SEBS, EVA and EBA polymers. Journal of Materials Science 34 (1999) 3737 - 3745.

Navarro FJ, al (2007). Rheology and microstructure of MDI-PEG reactive prepolymermodified bitumen. Mech Time-Depend Mater.;10(4):347-59.

RAMOND G. al (2000) . Caractéristiques de bitumes utilisés en Algérie, Bulletin de liaison ponts et chaussées, $\mathrm{N}^{\circ} 225$, pp 3-11, 2000. BLPC $\mathrm{N}^{\circ} 225$ Pp 3-11.

Merbouh M 2010. Contribution à la modélisation du comportement rhéologique des enrobés bitumineux: influence des conditions extrêmes de température et de trafic en fatigue. PHD Thesis university of Bordeaux 1.

Bahia, H. U et.al (1995). Strategic highway research program binder rheological parameters: Background and comparison with conventional properties. Transportation Research Record 1488, Transportation Research Board, Washington, DC, 32-39.

NGUYEN D-T (2006), Prédiction des déformations permanentes des Couches de surface des chaussées Bitumineuses, PHD thesis Ecole Nationale des Ponts et Chaussées, France.

Recommandations Algériennes sur l'Utilisation des Bitumes et Enrobés Bitumineux. 
Organisme de Contrôle Technique des Travaux Publics. Ministère des Travaux 2 Public, Algérie ; 2004.

Table 1. Physical properties of bitumen.

\begin{tabular}{|c|c|c|c|}
\hline Test & Results & Standard & $\begin{array}{c}\text { Specification } \\
\text { Limits [19] }\end{array}$ \\
\hline $\begin{array}{c}\text { Penetration } \\
(1 / 10 \mathrm{~mm})\end{array}$ & 38 & $\begin{array}{c}\text { ASTM D5 } \\
\text { EN 1426 }\end{array}$ & $35-50$ \\
\hline $\begin{array}{c}\text { Softening point } \\
\left({ }^{\circ} \mathrm{C}\right)\end{array}$ & 52 & $\begin{array}{c}\text { ASTM D36 } \\
\text { EN1427 }\end{array}$ & $50-58$ \\
\hline Specific gravity & 1.029 & ASTM D70 & $1.0-1.1$ \\
\hline Ductility $(\mathrm{mm})$ & $>1000$ & ASTM D113 & $>600$ \\
\hline
\end{tabular}

9

\section{TABLES}

Table 2. Chemical analysis of aggregates.

\begin{tabular}{|c|c|}
\hline Chemical analysis & Testing results \\
\hline Insoluble $(\mathrm{SiO} 2+$ silicates $)$ & $13.4 \%$ \\
\hline Perte au Feu à $1050^{\circ}(\mathrm{PF})$ & $37.04 \%$ \\
\hline$\left(\mathrm{Fe}_{2} \mathrm{O}_{3}+\mathrm{Al}_{2} \mathrm{O}_{3}\right)$ & $1.80 \%$ \\
\hline Sulfates $\left(\mathrm{CaSO}_{4}, 2 \mathrm{H}_{2} \mathrm{O}\right)$ & Traces \\
\hline$(\mathrm{NaCl})$ & $0.17 \%$ \\
\hline$\left(\mathrm{CaCO}_{3}\right)$ & $81.90 \%$ \\
\hline $\mathrm{CO}_{2}$ & $37.04 \%$ \\
\hline
\end{tabular}

Table 3. physical properties of waste NBR modified bitumen

\begin{tabular}{|c|c|c|c|}
\hline Properties & BW 2 & BW 3 & BW 4 \\
\hline Penetration $\left(25^{\circ} \mathrm{C}, 0.1 \mathrm{~mm}\right)$ & 27.3 & 29 & 31 \\
\hline Softening point $\left({ }^{\circ} \mathrm{C}\right)$ & 52 & 53 & 54.5 \\
\hline
\end{tabular}

\section{FIGURES}

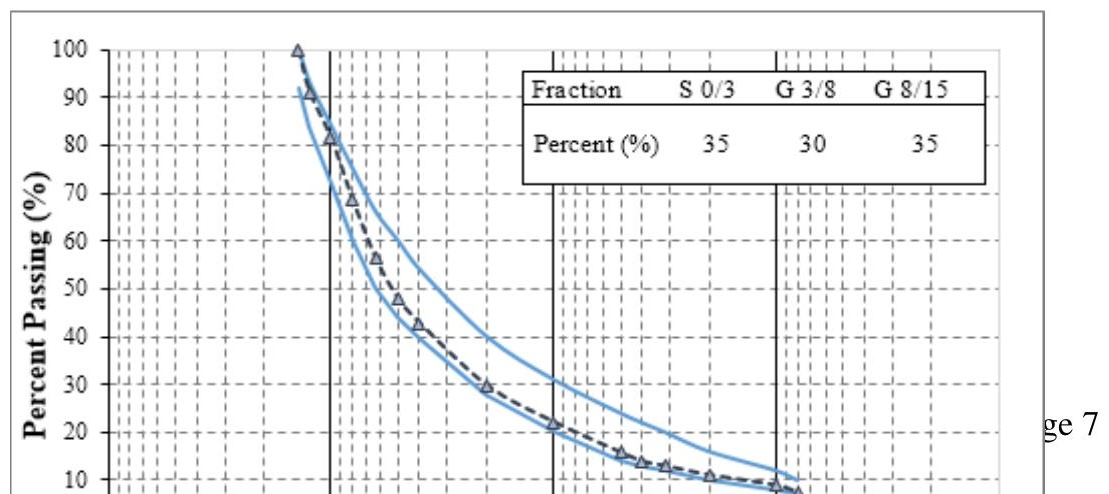


FIG. 1. Grain seize distribution of both control mixtures.

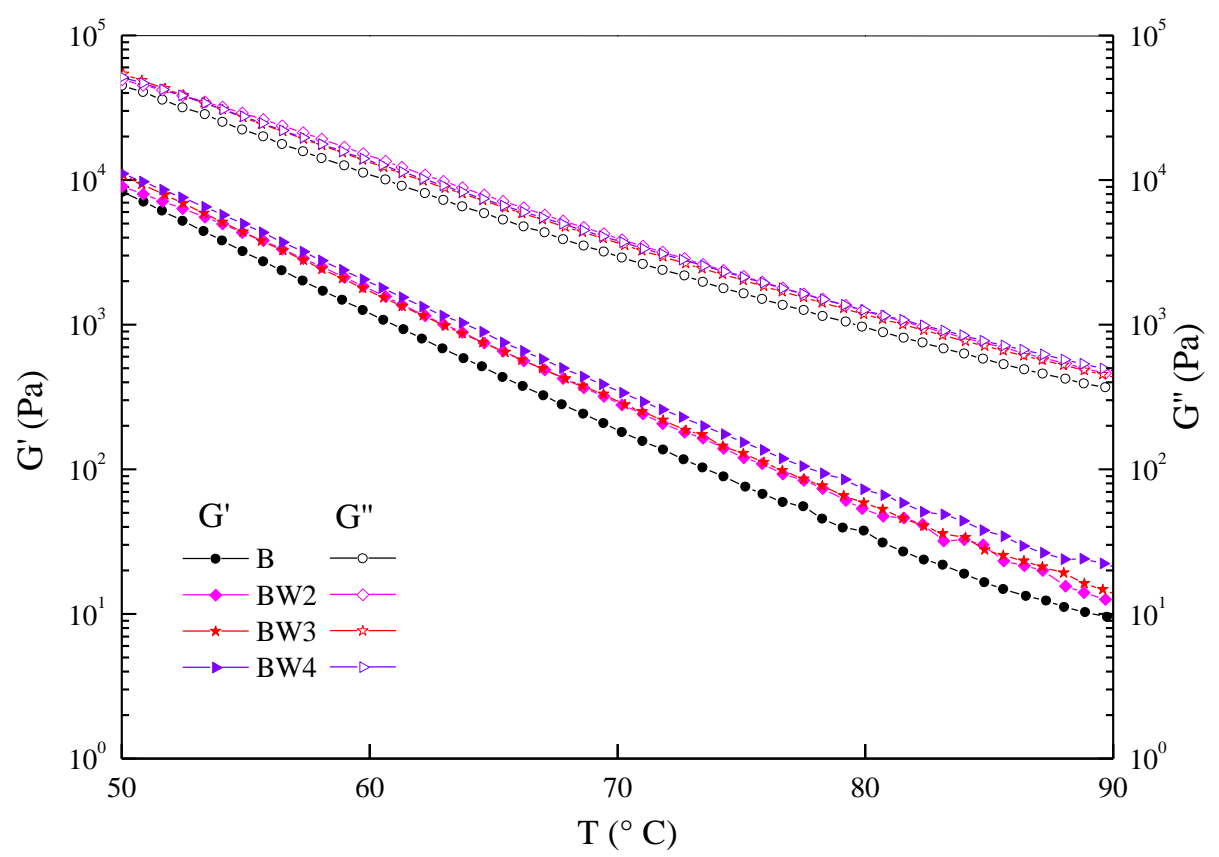

FIG. 2. Temperature dependence of the linear viscoelasticity functions, at $10 \mathrm{rad} / \mathrm{s}$, for the blend tested. 


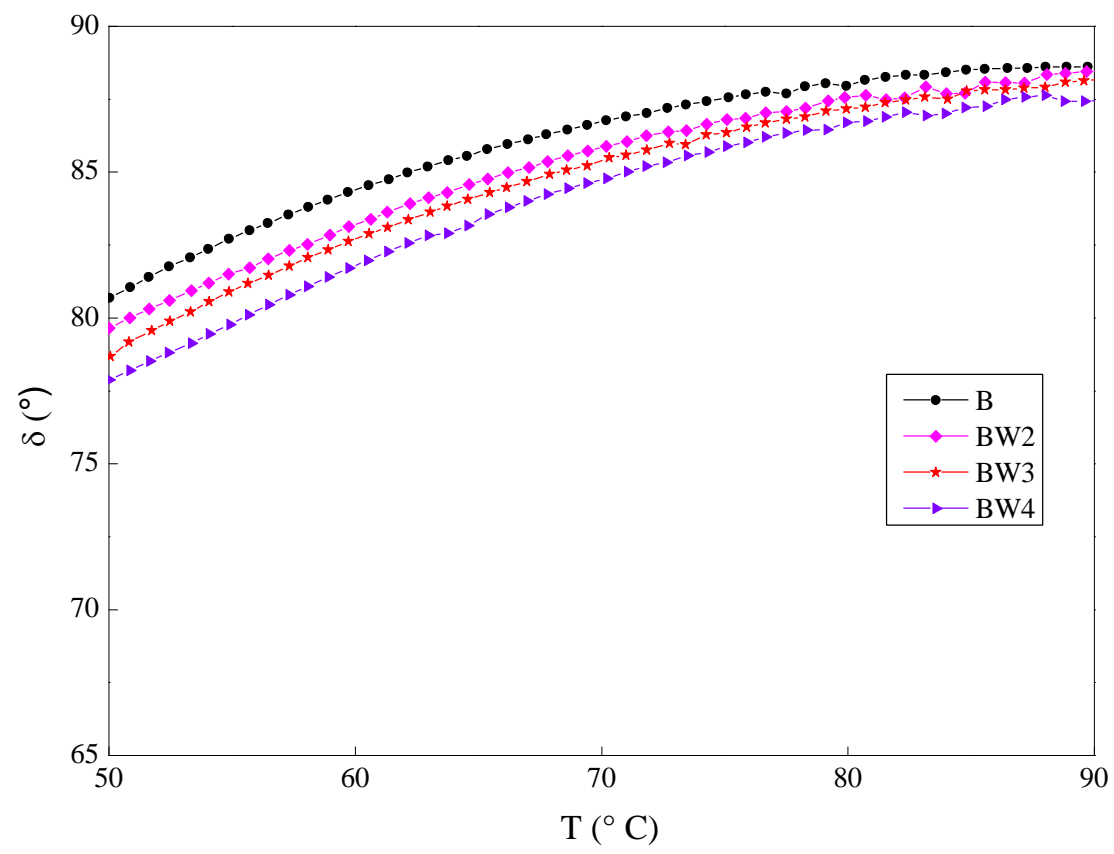

FIG. 3. Temperature dependence of the phase angle, at $10 \mathrm{rad} / \mathrm{s}$, for the blend tested

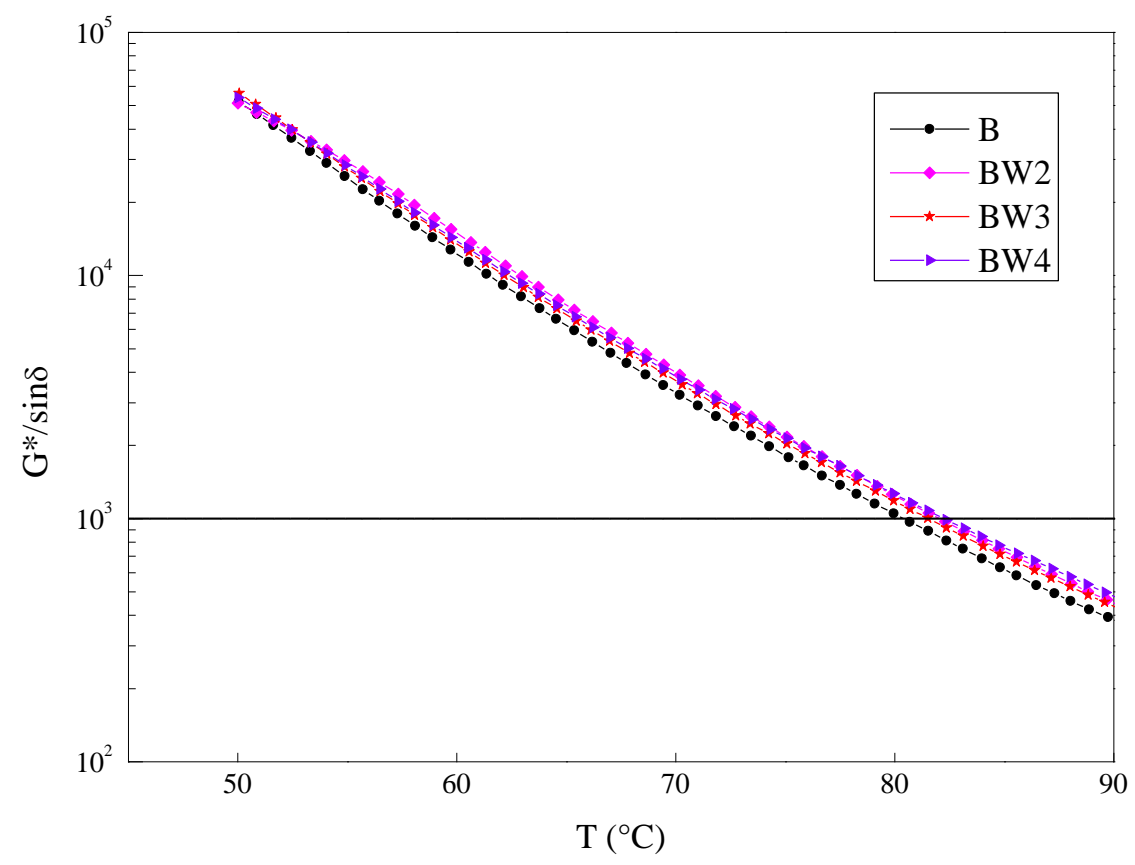

FIG. 4. Curve of $\mathrm{G} * / \mathrm{sin} \delta$ measured at $(10 \mathrm{rad} / \mathrm{s})$ as a function of temperature. 


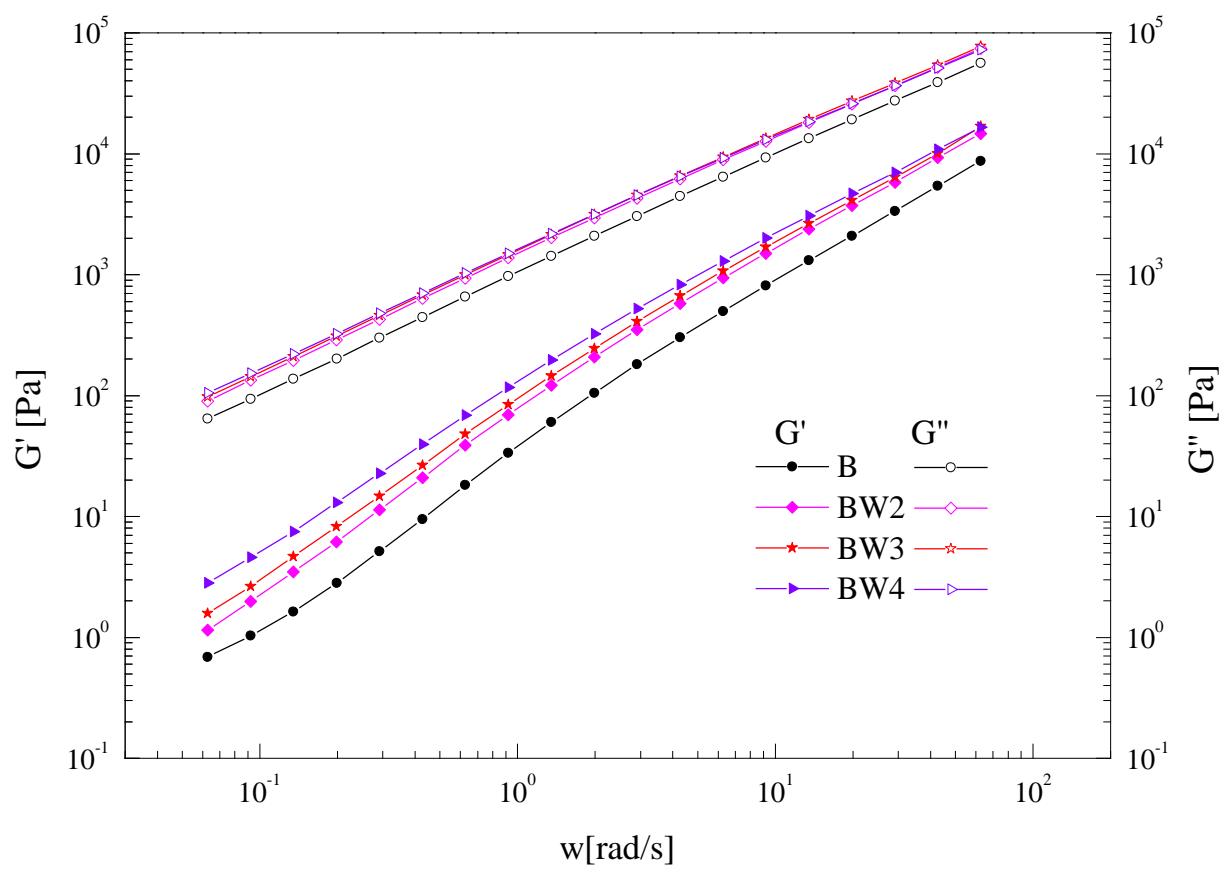

bitumen and the different blends

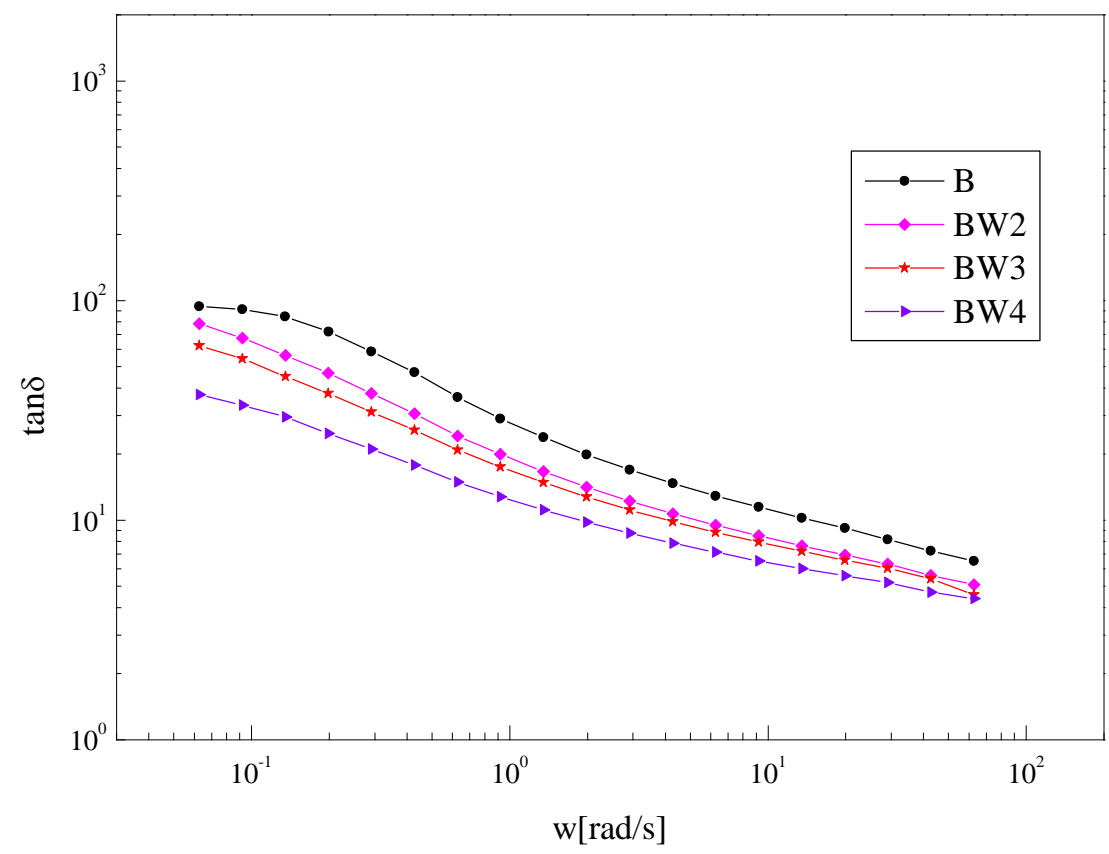

FIG. 6. Isochronal plot of tan $\delta$ at $60^{\circ} \mathrm{C}$ 


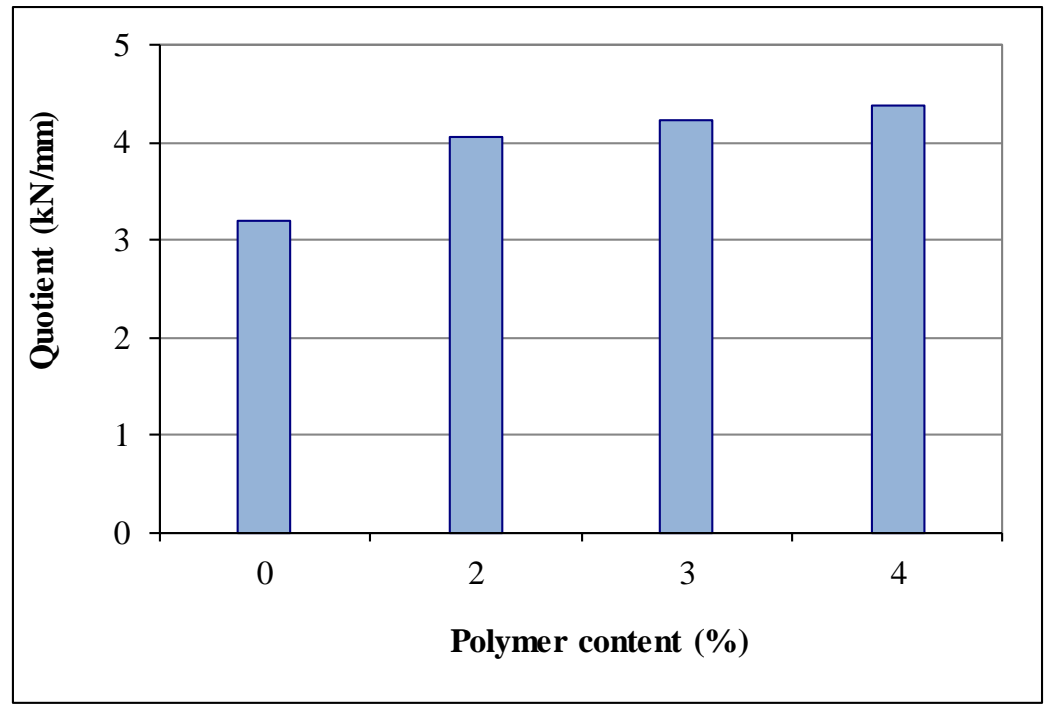

FIG. 7. Marshall Quotient of the different asphalt mixes versus the waste NBR content.

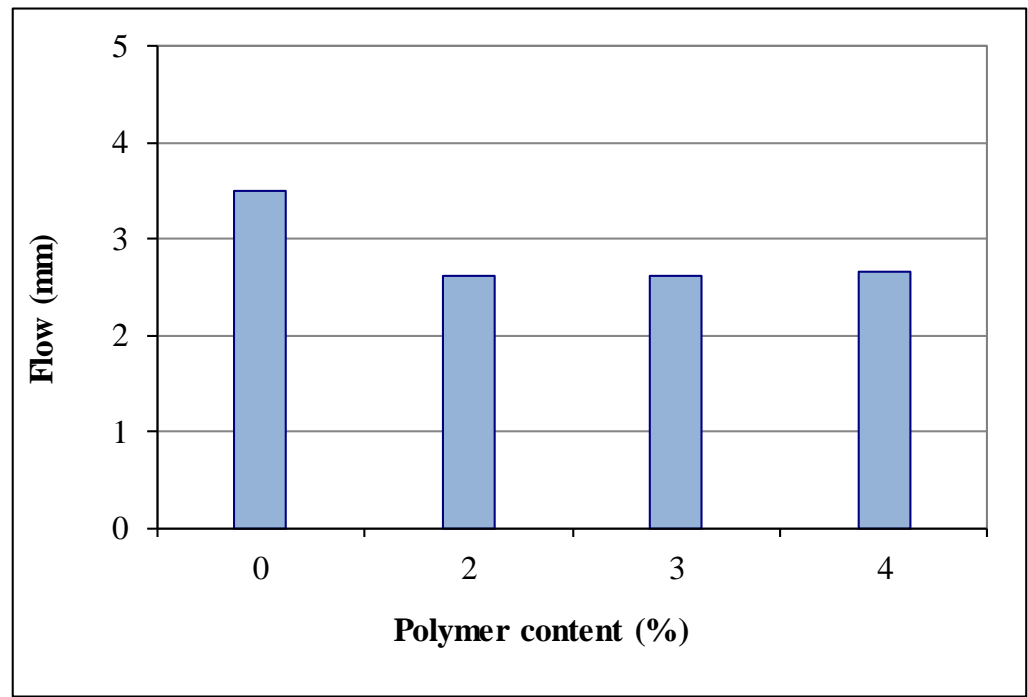

FIG. 8. Marshall flow of the different asphalt mixes versus the waste NBR content. 